UDK 821.111(73)-3.09"195/20"

\title{
GENERATION X IN SLOVENIA(N)
}

\author{
Romi Češčut
}

\begin{abstract}
Addressing themes of family, interpersonal relationships, historicity, jobs, religion, and apocalypse Generation X narrative includes works by young American writers in the 80s and 90s of the twentieth century. The search for one's identity in urban landscape is heavily influenced by mass media, pop culture and consumerism. Slovenian press and professional literature provided only scarce response to Generation X fiction which is also influenced by the ambiguity of the term Generation $\mathrm{X}$ and the essence of its culture and literature, which is also true for American literary criticism. The paper aims to explore the reception of novels by Douglas Coupland, Bret Easton Ellis, and Jay McInerney and their analyses with emphasis on narrative, themes of consumerism and mass media, characters, and style of writing.
\end{abstract}

Key words: Generation X, American generations, brat-pack, Douglas Coupland, Bret Easton Ellis, Jay McInerney

\section{GENERATION X FICTION}

Generation X literature was mainly produced by the younger generation of American authors in the 80s and 90s of the twentieth century. The sole term 'Generation X', though itself ambiguous in essence and meaning, became widely used after the release of the first novel Generation X: Tales for an Accelerated Culture (1991) by Canadian writer Douglas Coupland. It is an account of three people that move to a Californian desert suburb to escape consumerism and pop culture, and tell each other stories to make their lives meaningful. The same year, the first film by a young American director, Richard Linklater, Slacker, with similarities to Coupland's novel introduced jobless young people that rejected the norms and rules imposed by society. As soon as media found the third phenomenon - a new kind of music, 'grunge', that expressed contemplation, looked for extremes and meaning of life beyond one's striving for success and profit, a stereotype about Generation X was born. Thus, Generation $\mathrm{X}$ became synonymous with a group of young people and later on with a whole demographic group born approximately between 1960 and 1980 in the USA. 
So far, literary criticism has not provided adequate criteria for placing authors and works into the Generation X fiction. With the exception of Douglas Coupland, there has been partial agreement on the essence of Generation $\mathrm{X}$ as a term, demographic group, its literary characteristics and list of authors. My criteria for selecting Generation X authors and characteristics are based on the following critical thought: firstly, Eric Liu in the editorial to the first anthology on Generation X Next: Young American Writers on the New Generation (1994) believes that Generation X authors have the same and unique worldview, they are a "postboomer" generation, and know and understand media (Liu viii) $)^{1}$. Similarly, according to David Foster Wallace the "Conspicuously Young writers" share "the new and singular environment in and about which [they] try to write fiction" (Wallace 3) which is more important than the same age group ${ }^{2}$. Douglas Rushkoff, editor of the next anthology The GenX Reader (1994) stresses self-reference, self-reflexiveness and ironic distance of the works ${ }^{3}$. Moreover, James Annesley in Blank Fictions (1998) thinks the group does not represent a literary movement but a spirit of age reflecting an "atomized nihilistic worldview" (Annesley 3 ) with themes of sexuality, violence, media and consumerism (Annesley 1-2) ${ }^{4}$. Kenneth Millard in Contemporary American Fiction (2000) states that Generation X works "are self-consciously aware of their own status as market commodities, to be merchandised, advertised, promoted, packaged, and shifted as so many units of "product""5 (Millard 146). They display "the new freedoms and perils of American corporate enterprise and the sometimes violent personal alienation that can accompany it" (Ibid.) and the depthlessness of the American society in the twentieth century, its satire and its crisis of values. Next, Daniel Grassian in Hybrid Fictions: American Literature and Generation X (2003) defines Generation $\mathrm{X}$ narratives as 'hybrid fictions' which describe the empty lives of the young white Americans in urban parts of the USA and express a critique on the effects of popular culture on them ${ }^{6}$. Finally, the doctoral thesis Ameriško literarno gibanje avant-pop (2002) by Mojca Krevel, states that growing up in the 80s, adulthood in the 90s, subversion and characters' distance to mass media (Krevel 83) are important features of avant-pop which I believe can also be ascribed to Generation $\mathrm{X}^{7}$.

${ }^{1}$ Liu's anthology includes essays by the following authors: Jenny Lyn Bader, Stephen Beachy, Paula Kamen, Ian Williams, Naomi Wolf, Paul Beatty, Cathy Young, David Greenberger, Ted Klein, Karen Lehrman, Lalo Lopez, Robin Pogrebin, and Elisabeth Wurtzel.

${ }^{2}$ In his 1988 essay "Fictional Futures and the Conspicuously Young” Wallace mentions Ellis, McInerney, Janowitz, Leavitt, Simpson, and Minot.

${ }^{3}$ Rushkoff's anthology incorporates fragments of works by Douglas Coupland, Walter Kirn, Bruce Craven, Darius James, and Marc Laidlaw and Rudy Rucker.

${ }^{4}$ Annesley classifies works by authors Donna Tart, Susanna Moore, Douglas Coupland, Sapphire, Katherine Texier, Mark Leyner, Ray Shell, and Evelyn Lau as 'blank fiction' and its authors as successors of the literary 'bratpack'. Its main representatives are Bret Easton Ellis and Jay McInerney, whose works from the 80 s of the twentieth century thematize discontent, decadence, brutality, violence, sexual experimentation and drug abuse of young Americans.

${ }^{5}$ The characteristics refer to Kathy Acker's In Memoriam to Identity, Douglas Coupland's Microserfs, Douglas Rushkoff's Media Virus, and Bret Easton Ellis's American Psycho.

${ }^{6}$ Grassian's idea of 'hybrid fictions' refers to works by David Foster Wallace, Richard Powers, Neal Stephenson, William Vollman, Douglas Coupland, Sherman Alexie, Michael Serros, and Dave Eggers (Grassian 12).

${ }^{7}$ Mark Amerika, avant-pop artist and its founder, considers two of the aforementioned authors Mark Leyner and William Vollmann to be avant-pop authors (Krevel 27, 28). Larry McCaffery in his avant-pop 
My research was focused on Coupland's novels Generation X, Shampoo Planet (1993), Life After God (1995), Miss Wyoming (2001), All Families Are Psychotic (2002), Hey Nostradamus! (2004) and essay collection Polaroids from the Dead (1997), Ellis's novels Less Than Zero (1986) and American Psycho (1991), McInerney's Bright Lights, Big City (1984) and Story of My Life (1989), Hornburg's Bongwater (1995) and Downers Grove (1999), and Gomez's novel Our Noise (1995). Generation X narrative displays poorly developed characters without moral values, alienated, aimless and indifferent jobless white young people who oppose the norms and expectations of the society. Besides taking place in natural environments (forest, primeval forest and desert) the novels are set in urban (metropolitan) areas in the USA in the present day. Driven by the search for one's own identity and meaning in the American society at the end of the twentieth century, which is marked by consumerism; and mass media; and culture and history that became commodities, they address the themes of family, interpersonal relationships, jobs, religion, historicity and apocalypse. The theme of family displays an extended family, bringing together partners and children from different marriages, in which children miss their parents' love and education. As a result, they resort to media and pop culture and later on either become media savvy, their victim or enemy. Aiming at escaping the influence of the omnipresent media and consumerism some characters move back to nature or mythological places, yet their attempts fail in the end. Being brought up without religion, many discover a need to believe in something and consequently find their own source of belief in nature, self, friends or mistake it for consumerist activities. Religion helps characters overcome personal distress caused not only by poor interpersonal relationships but also lack of jobs. Most opt for a 'McJob', "a low-pay, low-prestige, low-dignity, low-benefit, no-future job in the service sector" (Coupland 1991: 6), as they have no other possibility or want to flee from responsibility. Living for the present, suffering from 'information overload' and with experience mediated through mass culture and media, the characters do not address history as an important issue. It is reduced to a commodity and connected with one's search for his or her own roots, or to a thematic park. Lastly, drugs, present in private and public life and easily attainable, together with death, illnesses, and disasters give the narratives an apocalyptic character.

Predominantly composed in prose in form of a novel, Generation X fiction is fragmented and loose in structure, and written mainly in the first person singular in the present tense. Coupland's early works (Generation X, Shampoo Planet and Life After $G o d)$ are unconventional for their use of hypertext. The author has created a system of footnotes in the form of illustrations, comics, comments and catchwords that break the narrative and distract the reader. Yet, this way a frame or context for the text is created which is as equally important as the text itself. Generation $\mathrm{X}$ narratives are rich with

anthology After Yesterday's Crash (1995) places 'bratpack' authors and 'slackers' into the youngest generation of avant-pop (Ibid. 81). Leyner's My Cousin, My Gastroenterologist, Et Tu Baby, and Tooth Imprints on a Corn Dog, Coupland's Generation X, Shampoo Planet, Microserfs, and Girlfriend in a Comma, Kathy Acker's Blood and Guts in High School, Great Expectations, Don Quixote, Empire of the Senseless, Pussycat, King of the Pyrates, and In Memoriam to Identity, Darius James's Negrophobia, David Foster Wallace's The Broom of the System are classified as avant-pop. DeLillo's White Noise and Mao II, Ellis's American Psycho and newer short stories by Marc Laidlaw, authors William T. Vollman and Lynne Tillman are also included into avant-pop fiction by Krevel (Ibid. 39). 
quotes and metaphors referring to music, film, media events and cult authors and literary works which indicates that these narratives, popular culture and media became interrelated. The most recurrent trope is metonymy which exemplifies the use of products of mass consumption and their names, and brand names to create the environment, situations and characters, and to give the novels a geographical and historical frame. The language consists of internal jokes, quotes, comparisons, phrases and neologisms from popular culture. Ellis's Less Than Zero and American Psycho stand out due to accurate and objective descriptions of the events. What is more, the conversations in the first novel resemble the flow of images in an MTV video, while in the latter; Bateman's voice oscillates from reviews, yellow press articles, movie jargon, and political addresses to commercial brochures and catalogues.

\section{GENERATION X IN SLOVENIA(N)}

\section{Critical thought on Generation X group and narrative}

In Slovenia there is no correlate to the demographic group born between 1960 and 1980 in the USA and the Western world. The first to mention the term "Generation X" was Ženja Leiler in Delo, 1995, referring to an international group of young film directors. Nataša Velikonja in her article "Korporativne generacije" in Primorska srečanja in 1996 states that Generation X denotes an American post yuppie generation which has been trying to find out some basic values in life since the beginning of the 90s (Velikonja 738). Set against authorities, more tolerant and not oriented in career progress, its members are under the influence of the media - thus corporations, such as MTV or CNN, which feed them with fast, unargumented and disconnected images. Their culture consists in collecting, recycling and modifying music, art and fashion from the previous decades rather than creating their own. Velikonja's article ends with a belief that Generation X has reached an end (Ibid. 737-738). Bojan Musil and Boštjan Sirnik in "Generacija X. In memoriam generaciji, ki je nikoli ni bilo" from Sobotna priloga Dela, 1999, assert that Generation X got its name from the title of the first novel Generation $X$ by Coupland in 1991. The same year, the first film by Richard Linklater, Slacker, and Nevermind, an album by the Seattle grunge music group Nirvana were released. Even though the neologism 'Generation X' appeared quickly and no one knew exactly what it meant at the time, the authors believe it describes young and cynical young people who are resigned to their fate. These frustrated young 'slackers' have their own fashion, listen to alternative music and still live at home with their parents since they are unable to find a proper job (Musil and Sirnik 37). Further on, the authors describe the evolution of the term 'Generation X' - stemming from the work Class by Paul Fussel and later on encompassing a group of young people, a brand name and a myth misused by economy, marketeers and politicians. However, the death of Nirvana's singer Kurt Cobain and Coupland's declaration on $\mathrm{CNN}$ that Generation X does not exist but is rather a metaphor for a worldview, which was supported by his article in Details magazine, announced that Generation X was coming to its end. The authors conclude that this illusive social phenomenon represents a worldview that reflects a spirit of time. It resembles a collec- 
tion of different and opposing values and points of view which derive from subjective opinions by authors themselves or stereotypes by critics. "[Generacija X predstavlja] postmodernistični kolaž različnih, celo nasprotujočih si stališč, vrednot, življenjskih stilov ... saj gre za subjektivno naravnana prepričanja oz. stereotipe raziskovalcev ali zagnanih pripadnikov, ki so skušali ta konstrukt braniti” (Ibid.).

Dragica Sušnik in her 2002 article "Generacija Y. Trezni in odgovorni, romantični in ljubeči" which was published in Glamur magazine believes Generation X is a generation and describes it from the sociological point of view and compares it with generation Y. Being conformists, skeptical about politics and not inclined to revolutions as their predecessors 'baby boomers' were, the Generation X members do not live for their jobs and tend to change them. Most opt for "McWork" ("Mcdelo"), i.e. safe but badly paid jobs (Sušnik 39) and thus their employers characterize them as lazy and incapable of long term concentration. Exposed to sensory overload from mass media, they feel that they have experienced everything, and have difficulties in finding the right partner. Due to financial insecurity and comfort they still live with their parents. Living in a society marked by unemployment, crime, ecologic catastrophes and aids, they are cynical, apathetic, and pessimistic about the future. Sušnik also describes how the term "Generation X" evolved, and concludes that Generation X was a myth and a marketing construction that offered identification to millions of young people (Ibid.). The article "Mladina v sodobni družbi", 2006, by Danica Šaponja discusses the last four generations in Slovenia focusing on generation Y. She believes Generation X is synonymous with a demographic group whose members are children of parents who put their career and economic welfare before family and individual life. At this time, according to Šaponja, women became independent, family relationships changed which resulted in numerous divorces. Growing up, Generation X saw the media becoming more powerful, witnessed the increase of violence in schools and on television, homelessness, and finally ecologic awareness. Having replaced their missing parental education with peer education, they strictly divide private life from work, where they are flexible and frequently self-employed. Generation X members do not accept traditional values such as loyalty and collective duty which originated from historical ideologies, but values that are close to an individual and his or her experience (Ibid. 11). Their children, generation $\mathrm{Y}$, are postponing the period of adulthood and seeking financial and emotional support of their parents. The values of social and material security, friendship and interpersonal relationships, personal development, the quality of everyday life and an unpolluted environment are appreciated by both generations.

\section{Critical thought on Generation $X$ authors and works}

Most critical thought relates to works by Bret Easton Ellis, less to Douglas Coupland's or McInerney's works. After examining criticism on Coupland and his work I will proceed with Ellis and his novels Less Than Zero and American Psycho.

Jure Stojan in his article "Douglas Coupland: Miss Wyoming. Ljubezenska prigoda" in Večer, 2001, describes Coupland as a cult writer next to Kerouac, Burroughs, Vidal, Ellis, and Houllebecq. Capturing the spirit of time in his works and perceiving 
movements in society and predicting trends, he caught the attention of a younger public. Although his works have weak plot and structure, Stojan believes Coupland did an excellent job in describing a generation which grew up in the 80s and found itself on the job market in the 90s of the twentieth century. The author praises Coupland's style as being readable and full of witty remarks and comments, yet his writing is attractive and interesting only on the surface. The long awaited and much advertised novel Miss Wyoming, which differs from his cult works Generation X; Shampoo Planet; and Microserfs, is according to Stojan not successful as it is based on coincidences and flat characters. It could be considered a satire on the contemporary society or a parody of lower literature genres. Coupland often analyzes past actions which influence the present plot and as a result, the structure of the novel is complicated. Finally, according to the author, the novel is serious, sincere, and includes a witty observation of its time and "sledi Couplandove mojstrske površinskosti" ("traces of Coupland's masterly superficiality") (Stojan 11). Urša Primožič in her 2004 seminar paper "Douglas Coupland's Generation X: Tales for an Accelerated Culture" provides Coupland's biography and bibliography, the origin, use and meanings of the term 'generation X' (Primožič 6), and the contents of the novel. She believes it to be different from the previous generational novels as it offers only stories and no answers. The end of the novel is open; we do not learn if the characters were able to fulfill their dreams in the desert. Moreover, the main characters tell each other stories, which have a therapeutic effect in expressing their feelings and comments of the consumerist society. For example, "Texlacoma story" could be a parable of the characters' inability or lack of will to fall in love and have a relationship (Ibid 21). Then, Andy shares the story about Edward only with the reader and not with Claire or Dag. Edward who is the narrator's alter ego has not been in love yet but wants to have a relationship, this is also true for Andy. Following the description of the main characters, Primožič focuses on form and language. The first person narrator of the story, Andy, "commenting on life via stories and descriptions [...] does not judge or make conclusions" (Ibid. 15); this is left to the reader. The novel is composed of three parts and "all chapters in the book carry meaningful titles that comment on the content of the chapter" (Ibid.) which forces the reader to read and understand the novel on multiple levels thus creating a hypertext. Numerous neologisms, comics, illustrations and bumper stickers in the form of footnotes carry the same meaning as the text and in this way they represent a hypertext which is a mixture of the narrator's and Coupland's voice. Some footnote neologisms appear in the text itself, others are only defined or exemplified by similar phenomena in the text. To understand their irony, sarcasm or black humor the reader's knowledge of pop culture and mass media is required. Providing examples and motifs from the novel, Primožič believes the main themes of the novel are escape from society and striving for love and a relationship. Further on, she asserts the novel to be avant-pop as its content is oriented against mass media and consumerism. Telling each other stories, the characters communicate through stories - "via something unreal, via a simulation" (Ibid. 23). The term Generation X is itself a simulacrum in real life - a copy without an original. Namely, a book title became a name for a group of people (Ibid.). Another characteristic of avant-pop and this novel is a new understanding of literature. The division between what is real or what is fiction is disappearing, and consequently everything that helps create reality is acceptable. Moreover, texts which include hyper- 
texts cannot be read in a linear fashion, but on multiple nonlinear levels. As a result, the reader's role is increased - by choosing the level he creates the text, while the author's role is diminished - he has to provide component parts for the text (Ibid. 24). Primožič states that art in postmodern age bases on recycling and that the borders between high and low culture are blurred. Not only does history appear in the form of fantasies about past images from pop culture, and retro styles, but the characters have also lost a sense for the past as they live in a permanent present. The author concludes that the novel Generation $X$ is timeless since it captures "the feelings of America's middle class generation of Reagan, planned parenthood, TV, and low economy" (Ibid. 26).

The first to write about Ellis's novel Less Than Zero was its translator Jure Potokar in the afterword to the novel, "Ledeni hlad bleščečega velemesta" (1989). He classifies the novel among new American prose, and does not ascribe it much artistic value. After the release it sold well and got good reviews as it addressed (rich) young people and its content and plot were not complicated. Potokar also mentions that Ellis did a course in creative writing and his first novel was compared to Salinger's The Catcher in the Rye (1951) which is also a generational novel. Due to its cultural specifics, involving status symbols, expensive clothes, exclusive clubs and drugs, the novel can be difficult to understand for both average Americans and Slovenians (Potokar 1989: 144). Described with cold objectivity characters without emotions fail to communicate with each other; take drugs; indulge in sex and prostitution; and are surrounded by mass media. Even though past events prove that the main character once had some values and emotions and is critical of his friends' nihilism, he does not act and leaves Los Angeles for the East Coast to continue studying at the end. Finally, the author believes the city with its empty citizens who are unable to communicate with each other, to be a metaphor for solitude. Aleš Debenjak in his comment on the dust jacket of the book (1989) also states the novel's success, translations into many languages, and compares it with Salinger's Catcher in the Rye. Yet, while Salinger's novel is warm and positive and features juvenile opposition to society, Ellis's novel consists of descriptions of recurrent parties, drug use, prostitution and sex. Its structure resembles television videos, and the rhythm of changing video clips. Young people, who are not socially engaged have access to everything, yet are not able to fulfill themselves (Debeljak 1989: unpagined). The novel with a simple structure is composed of simple sentences, "Hemingway sentences" (Ibid.). The characters exchange short replicas, their discourse is full of fillers, monosyllabic words and quotes from films, music and magazines which results in the inability to express one's feelings, experience and psychological states (Ibid.). According to an anonymous review in Knjiga magazine, 1989, authors of prose bestsellers are usually old and experienced, which is not true for Ellis, who was 18 when his novel was released. The author summarizes Potokar's and Debeljak's findings on the novel in terms of content, structure and the reasons for success. Andrej Blatnik in his 1989 article "Ledeno branje za vroče dni" (Teleks), thinks Ellis belongs to the 'new lost generation' (Blatnik 36). He compares the novel to Salinger's generational Catcher in the Rye, but the cold tone of the novel reminds him of Hemingway's The Sun Also Rises (1926). Less Than Zero has been much read due to its simple structure and clear contents and as it is adapted to a contemporary reader who does not read complicated literature. According to Blatnik, its structure resembles the infinite exchange of video clips and soap 
operas, and its excellence is that it "govori o ničemer" "speaks of nothing" (Ibid.) In his opinion, this generation of young American authors owe their good style of writing to creative writing workshops, yet their works lack emotions and anything "večjega od resničnosti" ("bigger than reality") (Ibid.). Matej Bogataj in his review "Vrla nova osemdeseta leta" (1989) from Dnevnik classifies Ellis in the 'non-generation' (Bogataj 12). This group of writers of the Reagan era which also includes David Leavitt, Jay McInerney, and Marian Thurm, experienced instant success in their careers (Ibid.). The characters in this novel are children from affluent dysfunctional families who are left alone and out of boredom take drugs and change partners. The narrative about the loss of feelings and profoundness is occasionally interrupted by memories of Clay's past when he was still able to feel and had a functional family. The novel excels in skillfully combining the past and present, describing parties, and in the narrator's indifference (Ibid.). Mentioning the influence of creative writing workshop on Ellis, Bogataj compares 'non-generation' authors with beat authors. Both consumed alcohol and drugs, yet beatniks' activity had a meaning; living on the edge, they searched for freedom; nonconformity; and a different, less alienated world. On the other hand, Ellis's generation is superficially successful, financially independent and sets trends. However, it is also anxious, unable to communicate, and bored with videos; only a murder or a dead body can break its state of apathy for a while (Ibid.).

Aleš Debeljak wrote about American Psycho in a review "Obsceno je nasilje" (1991) in Naši razgledi before the novel's USA release. After a brief analysis of Ellis's other works, the journey of the novel's problematic manuscript from Simon and Schuster to Random House is described. According to him, Ellis discovered the right elements for a successful novel which comprise "nasilje, sadizem, mizoginija in druge značilnosti "urbane džungle" ("violence, sadism, misogyny, and other characteristics of the "urban jungle"') (Debeljak 91). Moreover, he asserts the novel lacks the criticism which was present in his first novel, and which makes controversial literature historical, e.g. Dostoyevsky's Notes from Underground (1864). He supports the idea of the National Organization of Women who promised to boycott books by Random House if it published American Psycho. The text is problematic because it is obscene - including elements of violence, torture, rape and intentional pain which are shown as esthetic pleasure without any comment. The article "Bret Easton Ellis, Ameriški psiho" (1992) in Primorska srečanja by Tomo Vidic includes the author's own translation of a chapter. In his opinion, newer American authors like David Leavitt, Jay McInerney, Tama Janowitz, Joe McGinnis, Michael Chabon, David Mamet, Eric Bogosian, and Bret Easton Ellis are unfamiliar to the average Slovenian reader who does not read literature in English. He further states that Ellis's first novel was not successful in Slovenia. Vidic speaks about the journey of the manuscript and believes the novel did not receive good reviews being "pretirano krvava in sadistična knjiga, bolestna in degenerirana štorija" ("an excessively bloody and sadist book, a sick and degenerated story") (Vidic 1992: 153). According to him, it has "nenavadno sočen in slikovit jezik" ("an exceptional juicy and picturesque language"), it holds a mirror to the American society and presents a juncture of American dream and nightmare (Ibid.). The essay "Vprašanje zla" (1994) by Aleš Debeljak in Razgledi includes a chapter "Ubijanje psa" ("Killing Dog") translated by Jure Potokar, and it precedes the Slovenian release of the book. The author 
discusses the manuscript's journey and states the novel received major mass media attention; however, it did not get a single entirely positive review. So, it was Norman Mailer in the name of PEN who defended Ellis and his freedom of speech. Debeljak thinks the novel touched "nekega občutljivega socialnega živca" ("a sensitive social nerve") (Debeljak 1994a: 35), however, with his method of exaggeration Ellis succeeded in displaying the psychopathology of everyday life in a world controlled by media in which unmotivated evil becomes the main form of violence (Ibid.). If Clay in Less Than Zero critically observes the rape of a girl, Bateman's murders are random, unpredictable, unmotivated and his actions absurd in a world that has no meaning and where everything becomes acceptable. The author considers the work to be incomplete since Ellis does not explain the reason for Bateman's violence. The afterword to the book by the same author (1994) resumes the above article. Apart from this, Debeljak believes that the novel should be read considering the socio-historical frame of American culture at the end of the twentieth century. Ellis was irritated by reactions of the public and critics and stated his characters to be two-dimensional and as such unable to control their lives (Debeljak 1994b: 480). Together with Jay McInerney and Tama Janowitz Ellis represents a new literary trend - 'brat pack' (Ibid. 482). They became successful due to the fact that their works shifted away from metafiction, had a simple structure and were "mešanic[a] seksa, krvi, video iger, drog, elitnih klubov in prepoznavne pop ikonografije" (a "mixture of sex, blood, video games, drugs, exclusive clubs and recognizable pop iconography") (Ibid. 482). Ellis's technique of interrupting boring descriptive passages and enumerating lists with erotic or violent scenes creates an impression that violence and sexuality are connected or that violence derives from sexuality. On the other hand, enumerating trademarks, venues or exclusive clubs helps to stick the text parts together and prevent them from falling apart. Ellis's own critical distance to violence declares that violence is omnipresent. Debeljak deduces the novel is not naturalistic, since certain facts such as Bateman's job or the disappearance of his victims are rather doubtful. The article "Zlobno oko pošastnega Moby Dicka" (1994) in Primorske novice by Tomo Vidic includes an interview with the novel's translator Jure Potokar. The author assumes Less Than Zero was not popular in Slovenia as Slovenian readers could not relate to rich young Californians, drugs or expensive cars, which is also true for American Psycho. Potokar had difficulties in translating some passages that contain violence and torture, as well as neologisms, slang words, drugs and details from New York life. Since Bateman's world is very sophisticated including details from cosmetics, fashion or high technology, it is difficult for the reader to become familiar with it. Potokar lists Ellis, McGinnis, Janowitz, and McInerney into the 'brat-pack' generation. The group is not outstanding due to its being a result of creative writing workshops, commercials and publishers' enterprise (Potokar in Vidic 1994: 15). These authors have outsourced themselves and according to Potokar, only time will show their literary success. Potokar perceives the novel as a metaphor of the contemporary American society, and its structure of scene sequences reminds him of the video clip technique. The work is full of digressions, meaningless and banal conversations, nonsense words that aim at showing the emptiness of this social class, its confinement and lack of prospects (Ibid.). Potokar deems the Slovenian reader confused by Bateman's job, and by the narrative in present tense as he or she is not used to it. In conclusion, 
he praises the novel's picturesque, multi-level and enigmatic character, which comes into prominence in the last chapter. Marko Golja in his article "V praznini, onkraj užitka" (1994) in Primorska srečanja asserts the novel is important as it deals with the good, the evil and the meaning of life in a radical and brutal way (Golja 874). He feels the characters, yuppies, have no moral values; are shallow; superficial and unable to communicate with or understand each other, yet they master social behavior. Their descriptions comprise the first part of the novel, while the second half focuses on an individual - Bateman and his unmotivated murders. Being a part of the world without cause and consequence, Bateman identifies violence as an everyday phenomenon and he lacks the will to fight the nihilism and its emptiness (Ibid.). The anonymous article "Pošast je moralist" (1999) in Sobotna priloga Dela claims the novel to be one of the best in the second half of the twentieth century as it not only shows yuppies but also a world that has experienced everything. Ellis was annoyed by critics who argued his works do not respect ethic values. On the contrary, he considers it moral not to judge. Further on, the author compares the superficial world in the novel with hell where one's identity is established by clothes (34). Bored rich teenagers cannot differentiate between the real world and the world of drugs and video clips, and only violence seems real to them. Bateman resorts to violence to escape superficiality and engagement with his own psychological life, which is what Norman Mailer misses in the novel. The novel's reality is composed of images from mass media and lifestyle magazines, and the language, which is unconnected with things; events; suffering and pain, is not sufficient to express reality (Ibid.). The anonymous writer of the essay "Tiranija lepote, mladosti in bogastva" (1999) from Sobotna priloga Dela interviewed Ellis and the French writer Michael Houllebecq whose works address violence and sexuality. According to the author, Ellis has been disturbed by the fact that in the USA, where violence is of everyday occurrence and people do not even perceive it, his novels have been understood literally. His point in the novel is that one can escape a superficial and material world only with an extreme act such as murder (39). The novel is also a critique of an indifferent and shallow society and of violent behavior that is not punished. He states Americans are burdened with sexuality and place too much importance on the outlook, the result being that they are not satisfied with themselves. Mitja Čander in "Michael Houllebecq, Bret E. Ellis, Sarah Kane - Zgodba o telesu" from Sobotna priloga Dela, 2002, analyzes the function of the body and extreme violence in the works by these authors. Čander states the world in the 90s of the twentieth century became abstract and shaped by the media which changed communication into simulated messages. As the spirit became weak and unable to define itself, the body came into the center. In the world of Wall Street yuppies, who are obsessed with status symbols, the body denotes just another commodity. Being obsessed with his own body Bateman is convinced he can manipulate with other bodies - his victims - to show his superiority. Ellis thematizes the body since in the world of mediated images it appears to be the only remnant that holds the true self (Čander 28-29). Yet, in an atomized world, in which communication is impossible, Bateman's character is nonexistent, a simulation, an automaton. The author concludes that the only way for the body to wake the spirit is to enter by force into its sphere (Ibid.). Ana Vogrinčič in her essay "Pripovedništvo praznine. Obsesivno potrošništvo Ameriškega psiha" in Primerjalna književnost, 2003, explores the 
manifestations of consumerism in the narrative, narrative devices, and Bateman's constructed character. After explaining the term 'blank fiction', resuming Annesley she displays the characteristics of the fiction in terms of characters, style, authors, and themes. The author concentrates on consumerism as it is demonstrated on the level of the narrative and in the main character as a consumer. Further on, she provides the concept of consumerism, illustrates the response of the public and criticism of the novel, and the structure of the novel which consists of fragments. When addressing Bateman's relationship with the media, she analyzes Batman as a media user and his deranged perception of reality due to his inability to distinguish between the reality and mediated images. She doubts in the existence of Bateman's character as the novel offers little information on his family; apart from this, chapters with music reviews have a different tone, his colleagues persistently mistake him for others, and he even confesses his nonexistence to his secretary. In the end, Vogrinčič thinks the definition of 'blank fiction' is elusive and refers to younger "blank fiction" representatives. The M. A. thesis Vrednote ameriške družbe v delih Breta Eastona Ellisa (2004) by Lidija Stankovič defines values of the American society as presented in Ellis's works ${ }^{8}$. The author illustrates events of the 80s and 90s of the previous century from the frame of socio-history and pertaining literary history. Stankovič maintains that Ellis's work can be classified as postmodern literature, experimental realism, 'blank fiction', or 'bratpack' literature'. Successively, the author provides brief summaries of the novels with critical responses, and the following characteristics and values of the American society in the 80s and 90s of the twentieth century: materialism; consumerism and deindividualization of consumers; alienation of individuals in the modern society; individualism; emotional apathy; violence; the importance of status; the importance of image and the cult of fame and famous people; sexual and racial discrimination; racial intolerance; xenophobia; and hyperreality. Examining film adaptations of some novels, Stankovič evaluates the impact of Ellis's work in Slovenia and determines that Less Than Zero and American Psycho had most critical response. The final chapter contains an interview with Jure Potokar who translated both aforementioned novels. Potokar explicates how he became acquainted with Ellis's novels, the problems he encountered while translating them and what he considers exceptional about Ellis's writing. Aleksandra Jović in her undergraduate thesis Consumerism and the Media in Works by Bret Easton Ellis and Jay McInerney (2009) examines the influence of the media and consumerism on works by 'brat pack' authors Ellis and McInerney, focusing on their debut novels Less Than Zero and Bright Lights, Big City ${ }^{10}$. Introducing the elements of

\footnotetext{
${ }^{8}$ Her analysis is based on Ellis's Less Than Zero, The Rules of Attraction, American Psycho, The Informers, and Glamorama.

${ }^{9}$ Stankovič classifies Ellis into postmodern literature due to open endings of his novels, characters who are not psychologically developed, author's lack of critical distance, elements of pop culture, and "MTV narration" (Stankovič 18). Owing to experimentation in narrative and detailed descriptions he can as well be an experimental realist. Including themes of violence, sexuality, boredom, passiveness in a world influenced by mass media and consumerism, his works are considered 'blank fiction'. Being a member of the literary 'brat-pack', he is not influenced by academic tradition and established authors but is a "reporter" of the postmodern society (Stankovič 21 ).

${ }^{10}$ As it is known to me, Jovič's thesis is the first in Slovenian professional literature to introduce McInerney's biography, brief summaries of his novels, topics, and style of writing. It places emphasis on his first novel in "second person narrative on cocaine culture [which] started a trend of novels, which used the topic
} 
the American culture in the 80s of the twentieth century, she explores Ellis's and McInerney's biographies, topics in their novels and styles of writing. Finally, Jović compares the two "rivalry" novels (Jović 42) in terms of plot, setting, characters, style and language.

Although Slovenian literary criticism has not found a parallel group of Slovenian authors or literary works bearing the same or similar characteristics in form and content to those of American Generation X, I believe some minor influence exists. Firstly, the novel Pimlico (2006) by Milan Dekleva includes references to global and Slovenian music, literature and art. The phrase "Ameriški psiho" ("American Psycho", Dekleva 110 ) is used by a main character's friend to refer to the future state of mind of Slovenian yuppies, who are unaware of the fact that their behavior and essence are clownish, conformist and inflexible. Moreover, negative reactions by the Slovenian police officials who recognized themselves in the novel Čefurji raus (2008) by Goran Vojnovič remind us of the responses to American Psycho.

The Slovenian press and professional literature have different critical opinions on the essence of Generation X. Douglas Coupland and his work is mentioned by authors Musil, Sirnik, and Stojan, and an exhaustive analysis of the novel Generation X is provided by Primožič. Briefly referring to other members of 'brat-pack', most critics focus on Bret Easton Ellis's life, bibliography, background and predominantly negative critiques of his novels Less Than Zero and American Psycho. Vogrinčič resumes Ellis's biography, defines 'blank fiction' and centers on the influence of consumerism on character and narrative in American Psycho. Stankovič offers a detailed biography and bibliography of Ellis and presents the socio-historical background to his novels, as well as analyzes the values in the American society in his work. Jović focuses the influence of the media and consumerism on Ellis's Less Than Zero and Jay McInerney's Bright Lights, Big City. As only Less Than Zero and American Psycho have been translated into Slovenian, consequently, Slovenian readership is deprived of Generation X fiction, and also it remains unclear how Slovenian authors and their works have been influenced by Generation X fiction.

Ljubljana, Slovenia

\section{WORKS CITED}

Annesley, James. Blank Fictions: Consumerism, Culture and the Contemporary American novel. New York: St. Martin's Press, 1998.

Anon. "Bret Easton Ellis: Manj kot nič", Knjiga, 1989 (Vol. 9-10): 416.

Anon. "Pošast je moralist", Sobotna priloga Dela (14 August 1999): 34.

Anon. "Tiranija lepote, mladosti in bogastva”, Sobotna priloga Dela (30 October 1999): 39.

Blatnik, Andrej. "Ledeno branje za vroče dni”, Teleks (6 July 1989): 36.

Bogataj, Matej. "Vrla nova osemdeseta leta", Dnevnik (22 August 1989): 12.

Coupland, Douglas. Generation X: Tales for an Accelerated Culture. London: Abacus, 1991.

Čander, Mitja. "Michael Houllebecq, Bret Easton Ellis, Sarah Kane. Zgodba o telesu", Sobotna

of drugs and the lost generation" (Jović 33). 
priloga Dela (24 August 2002): 28-29.

Debeljak, Aleš. Essay on the dust jacket to Less Than Zero (Manj kot nič), Ljubljana: Založba Mladinska knjiga, 1989.

"Obsceno je nasilje", Naši razgledi (8 February 1991): 91.

"Vprašanje zla", Razgledi (21 January 1994): 35.

. Afterword to American Psycho (Ameriški psiho), Ljubljana: Cankarjeva založba, 1994. 477492.

Dekleva, Milan. Pimlico. Ljubljana: Cankarjeva založba, 2006.

Golja, Marko. "V praznini, onkraj užitka", Primorska srečanja, 1994 (Vol. 164): 874.

Grassian, Daniel. Hybrid Fictions: American Literature and Generation X. North Carolina and London: McFarland \& Company Inc. Publishers, 2003.

Krevel, Mojca. Ameriško literarno gibanje avant-pop: Avantgarda in postmoderna. Doctoral Thesis. Ljubljana: Faculty of Arts, University of Ljubljana, 2002.

Jović, Aleksandra. Consumerism and the Media in Works by Bret Easton Ellis and Jay McInerney. Undergraduate Thesis. Ljubljana: Faculty of Arts, University of Ljubljana, 2009.

Leiler, Ženja. "Generacija X in premik k evropski kinematografiji“", Delo (11 October 1995): 8.

Liu, Eric, ed. Next: Young American Writers on the New Generation. New York and London: W. W. Norton, 1994.

Millard, Kenneth. Contemporary American Fiction, Oxford: OUP, 2000.

Musil, Bojan and Sirnik, Boštjan. "Generacija X. In memoriam generaciji, ki je nikoli ni bilo", Sobotna priloga Dela (24 July 1999): 37.

Potokar, Jure. "Ledeni hlad bleščečega velemesta". Afterword to Less Than Zero (Manj kot nič). Ljubljana: Založba Mladinska knjiga, 1989. 477-492.

Primožič, Urša. "Douglas Coupland's Generation X: Tales for an Accelerated Culture", seminar paper. Ljubljana: Faculty of Arts, University in Ljubljana, 2004.

Rushkoff, Douglas. The GenX Reader, New York: Ballantine Books, 1994.

Stankovič, Lidija. Vrednote ameriške družbe v delih Bret Easton Ellisa. M. A. thesis. Ljubljana: Faculty of Arts, University of Ljubljana, 2004.

Stojan, Jure. "Douglas Coupland: Miss Wyoming. Ljubezenska nezgoda”, Večer (15 January 2001): 11.

Sušnik, Dragica. "Generacija Y. Trezni in odgovorni, romantični in ljubeči”, Glamur (September 2002): 36-40.

Šaponja, Danica. "Mladina v sodobni družbi”. Vesna Čuk, ed. Obravnava mladostnika s psihozo: zbornik prispevkov. Ljubljana: Zbornica zdravstvene in babiške nege Slovenije - Zveza društev medicinskih sester, babic in zdravstvenih tehnikov Slovenije, Sekcija medicinskih sester in zdravstvenih tehnikov v psihiatriji, 2006. 11-17. (web edition) http://www.pb-begunje.si/Osnova/ file.php?id $=527 \& d b=$ priponke (accessed 18 February 2009).

Velikonja, Nataša. "Korporativne generacije”, Primorska srečanja, 1996 (Vol. 187): 757-738.

Vidic, Tomo. "Bret Easton Ellis. Ameriški psiho", Primorska srečanja, 1992 (Vol. 130): 148-153. "Zlobno oko pošastnega Moby Dicka", Primorske novice (13 May 1994): 15.

Vogrinčič, Ana. "Pripovedništvo praznine. Obsesivno potrošništvo Ameriškega psiha", Primerjalna književnost, 2003, 26: 21-43.

Wallace, David Foster. "Fictional Futures and the Conspicuously Young". Review of Contemporary Fiction, (autumn 1988). (web edition): http://neugierig.org/content/dfw/ffacy.pdf (accessed 29 July 2008). 